\title{
Studies of Two Subpopulations of Human Lymphocytes Differing in Responsiveness to Concanavalin A
}

\author{
David Boldt, Sister Ann Marie Skinner, and Stuart Kornfeld \\ From the Departments of Internal Medicine and Biochemistry, Washington \\ University School of Medicine, St. Louis, Missouri 63110
}

A в S т R A с т We have identified two populations of human lymphocytes differing in responsiveness to the plant mitogen concanavalin A (Con-A). When peripheral blood lymphocytes are passed through a nylon column a population of lymphocytes highly responsive to Con-A adheres to the fibers while a second population of cells relatively unresponsive to Con-A emerges from the column. The untreated peripheral blood lymphocytes are termed "unfiltered" cells while the lymphocytes which pass through the column are termed "filtered" cells.

Under standard assay conditions the Con-A-stimulated DNA synthesis is 6.5 -fold greater, and the percentage blast formation is four-to fivefold greater in the unfiltered than in the filtered population. Mixing unfiltered with filtered cells fails to induce responsiveness in the latter indicating that a "helper" cell is not involved. The failure of filtered cells to respond to Con-A is specific for that mitogen since both populations respond nearly equally to erythroagglutinating phytohemagglutinin (E-PHA) and the poke weed mitogen (PWM). Binding studies with Con-A- ${ }^{181} \mathrm{I}$ demonstrate that the unfiltered population possesses approximately three times as many Con-A receptor sites per cell as the filtered cells, although both cell populations bind the mitogen with the same affinity (apparent association constant $[K]$ of $1.67 \times 10^{6} \mathrm{M}^{-1}$ ).

The relationship between Con-A binding and lymphocyte activation was determined by measuring the effect on DNA synthesis of incubating the two lymphocyte populations with increasing amounts of Con-A. The concentration of Con-A required for half-maximal stimulation of DNA synthesis was 5-14 times greater for the filtered cells. However in the presence of very high Con-A concentrations the filtered cells achieved a maximal rate of DNA synthesis approaching that of the unfiltered population. These data implicate the decreased

Dr. Kornfeld is a recipient of the U. S. Public Health Service Research Career Development Award, AM 50298.

Received for publication 4 May 1972 and in revised form 5 June 1972. number of Con-A receptor sites on the filtered cells in their failure to respond to low concentrations of Con-A. A crucial event in the activation of lymphocytes by plant mitogens may be the binding of a critical number of the mitogen molecules to the cell surface.

\section{INTRODUCTION}

The plant mitogens constitute a class of molecules that bind to specific cell surface receptors on lymphoid cells, inducing them to undergo blastogenesis and to synthesize DNA. Since the initial description of this phenomenon $(1,2)$ these agents have been widely used to study various aspects of the immune response, cell proliferation. and growth control mechanisms in vitro. Consequently an intense interest has been generated towards elucidating the precise mechanism of action of these interesting compounds (for reviews see references 3-5). We now report that lymphocytes from human peripheral blood can be fractionated on nylon columns into subpopulations which differ in their responsiveness to the phytomitogen concanavalin A (Con-A). ${ }^{1}$ The relationship between mitogen binding to cell surface receptors and activation of DNA synthesis has been investigated.

\section{METHODS}

\section{Materials}

Two preparations of Con-A were used in these studies and were demonstrated to yield equivalent results. Con-A was obtained from Miles-Yeda Ltd. (distributed by $\mathrm{Re}-$ search Division, Miles Laboratories, Inc., Kankakee, Ill.) and from Nutritional Biochemicals Corp., Cleveland, Ohio. Phytohemagglutinin-P obtained from Difco Laboratories, Detroit, Mich. was purified according to the method of Weber, Nordman, and Gräsbeck (6). The resultant erythroagglutinating phytohemagglutinin material (E-PHA) was a

${ }^{1}$ Abbreviations used in this paper: CLL, chronic lymphocytic leukemia; Con-A, concanavalin A; E-PHA, erythroagglutinating phytohemagglutinin; FITC, fluorescein isothiocyanate; PWM, poke weed mitogen. 


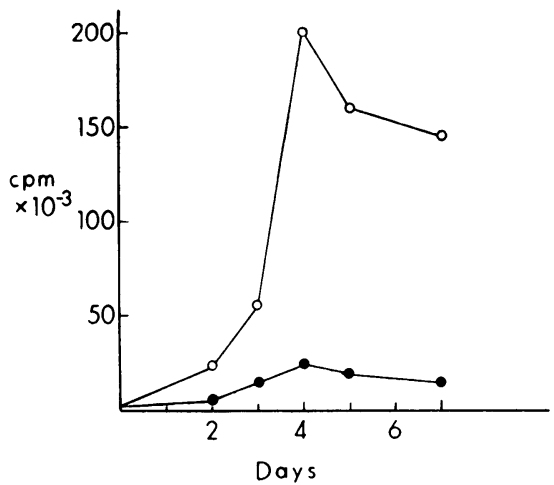

Figure 1 Time course of Con-A-induced DNA synthesis in filtered and unfiltered lymphocytes. Filtered and unfiltered cells were prepared and $2 \times 10^{8}$ cells were incubated with $12.5 \mu \mathrm{g}$ Con-A per $\mathrm{ml}$. On the days indicated cultures were pulse-labeled for $4 \mathrm{hr}$ with $3 \mu \mathrm{Ci}$ thymidine $-{ }^{3} \mathrm{H}$. Cells were harvested as described, and the incorporation of radioactivity into acid-insoluble material was determined. $\bullet$, filtered cells; $\bigcirc$ unfiltered cells.

potent mitogen and gave a single band on disc gel electrophoresis. Poke weed mitogen (PWM) was obtained from Grand Island Biological Co., Grand Island, N. Y. and was reconstituted according to the supplier's instructions. This company also supplied medium 199 in Earle's base and penicillin-streptomycin solution $(5000 \mathrm{U}$ penicillin and $5000 \mu \mathrm{g}$ streptomycin per $\mathrm{ml}$ ). Sigma Chemical Company, St. Louis, Mo. was the source of $\alpha$-methyl-D-glucoside, Ficoll (mol wt approximately 400,000), L-glutamine, and fluorescein isothiocyanate, isomer I. Pharmachem Corporation, Bethlehem, Pa. supplied dextran-grade $\mathrm{H}$ ( $\mathrm{mol}$ wt approximately 180,000 ), and sodium diatrizoate (Hypaque sodium, $50 \%$ w/v) was purchased from Winthrop Laboratories, N. Y. Thymidine-methyl- ${ }^{3} \mathrm{H}$ was obtained from New England Nuclear Corporation, Boston, Mass. Mallinckrodt Chemi-

TABLE I

Response of Unfiltered and Filtered Lymphocytes to Various Plant Mitogens*

\begin{tabular}{lrrr}
\hline & \multicolumn{2}{c}{ Thymidine- ${ }^{3} \mathrm{H}$ incorporated } & Ratio of response \\
\cline { 2 - 4 } Mitogen & Unfiltered & Filtered & Unfiltered/Filtered \\
\hline & & $c p m$ & \\
Con-A & 23,900 & 3,300 & 7.24 \\
E-PHA & 90,100 & 61,100 & 1.47 \\
PWM & 18,800 & 16,500 & 1.14 \\
None & 500 & 400 & 1.25 \\
\hline
\end{tabular}

* Unfiltered and filtered lymphocytes were prepared as described in Methods. Triplicate 2-ml cultures containing $2.0 \times 10^{6}$ lymphocytes were incubated for $72 \mathrm{hr}$ with 12.5 $\mu \mathrm{g} / \mathrm{ml}$ Con-A, $15 \mu \mathrm{g} / \mathrm{ml} \mathrm{E}-\mathrm{PHA}$, or $0.01 \mathrm{ml} / \mathrm{ml} \mathrm{PWM.} 3 \mu \mathrm{Ci}$ thymidine-methyl- ${ }^{3} \mathrm{H}$ were added to each culture for the final $4 \mathrm{hr}$ and the uptake into DNA was determined as described. The results are expressed as the average of triplicate determinations. cal Works, St. Louis, Mo. supplied reagent grade ${ }^{131} \mathrm{I}$. Nylon fibers were obtained from Leuko-Pak ${ }^{\circledR}$ leukocyte filters, Fenwal Laboratories, Morton Grove, Ill.; the nylon was soaked overnight in dilute acetic acid, then rinsed thoroughly in distilled water before use.

\section{Methods}

Preparation of unfiltered and filtered cells. Venous blood was drawn from healthy young adult donors. The blood was processed for the isolation of lymphocytes as previously described (7). Briefly, "unfiltered" cells consisted of a leukocyte population purified from defibrinated whole blood by dextran sedimentation and isopycnic centrifugation on a Ficoll-Hypaque mixture. Unfiltered cells contained 60-95\% lymphocytes, with erythrocyte contamination being less than 3\%. "Filtered" cells were prepared from unfiltered cells by passage through a $2.8 \times 6.7 \mathrm{~cm}$ column of nylon fibers $(7.0 \mathrm{~g})$ packed in a $50-\mathrm{ml}$ syringe. Generally $100 \times 10^{8}$ cells suspended in $7 \mathrm{cc}$ autologous serum were applied to the column which was then eluted with $100 \mathrm{ml}$ medium 199. The lymphocytes which passed through the column (30-60\% of those applied) are termed filtered cells. It should be noted that the unfiltered population includes the filtered cells in addition to granulocytes and monocytes which adhere to nylon fibers.

Lymphocyte incubation studics. For incubations of greater than $12 \mathrm{hr}$ duration, cells were suspended in medium consisting of medium 199 fortified with $20 \%$ autologous serum, $4 \mathrm{mM} \mathrm{L}$-glutamine, penicillin $50 \mathrm{U} / \mathrm{ml}$, and streptomycin 50 $\mu \mathrm{g} / \mathrm{ml}$. Where appropriate, serum was rendered free of complement by preheating at $56^{\circ} \mathrm{C}$ for $30 \mathrm{~min}$. All cultures contained between 2 and $4 \times 10^{8}$ cells suspended in $2 \mathrm{ml}$ of complete medium. $72-\mathrm{hr}$ incubations were carried out in $16-\mathrm{X}-125-\mathrm{mm}$ plastic screw top tubes (Falcon) at $37^{\circ} \mathrm{C}$ in an atmosphere of $5 \% \quad \mathrm{CO}_{2}$ and $95 \%$ air. The concentrations of the plant mitogens used were those determined as optimal on the basis of dose-response curves using unfiltered cells (data not shown). These concentrations were: Con-A 12.5 $\mu \mathrm{g} / \mathrm{ml}$; E-PHA $15 \mu \mathrm{g} / \mathrm{ml}$; PWM $0.01 \mathrm{ml} / \mathrm{ml}$ of media. Cultures were pulse labeled with $3 \mu \mathrm{Ci}$ thymidine-methyl- ${ }^{3} \mathrm{H}$ $(6.7 \mathrm{Ci} / \mathrm{mm})$ for the final $4 \mathrm{hr}$ of incubation. Cells were harvested as previously described (7) by washing once with cold $0.9 \% \mathrm{NaCl}$, adding $5 \mathrm{ml}$ cold $5 \% \mathrm{TCA}$, and sonicating $15 \mathrm{sec}$ at probe setting 40 on a Biosonik sonicator using a needle probe (Bronwill Scientific, Inc., Rochester, N. Y.). The disrupted cells were then centrifuged at $12,000 \mathrm{~g}$ for $10 \mathrm{~min}$ and the resulting pellet was washed with an additional $5 \mathrm{ml} 5 \%$ TCA and centrifuged again. The resultant acid-insoluble material was dissolved in 0.5 $\mathrm{ml}$ NCS solubilizer (Amersham-Searle, Corp., Arlington Heights, Ill.), and counted in $10 \mathrm{ml}$ Bray's solution (8) in a Packard Model 3380 Liquid Scintillation Spectrometer (Packard Instrument Company, Inc., Downers Grove, Ill.).

Lymphocyte binding studies. E-PHA and Con-A were iodinated with ${ }^{131} \mathrm{I}$ by the method of Hunter (9) using a $10 \mathrm{sec}$ exposure to chloramine- $\mathrm{T}$. Iodination of Con-A was performed in the presence of $0.2 \mathrm{M} \alpha$-methyl-D-glucose which was removed upon completion of the procedure by dialysis against $0.9 \% \mathrm{NaCl}$. Studies of $\mathrm{PHA}^{-131} \mathrm{I}$ binding to lymphocytes were performed as previously described (10). The marked tendency of Con-A to adhere nonspecifically to glass and plastic surfaces necessitated modifications in the techniques used to study Con-A- ${ }^{131} \mathrm{I}$ binding to lymphocytes. Binding studies were performed in Packard plastic counting tubes which had been presoaked for at least $12 \mathrm{hr}$ in $2 \mathrm{~g} / 100 \mathrm{ml}$ bovine serum albumin. After a 
$45 \mathrm{~min}$ incubation at $24^{\circ} \mathrm{C}$ with Con-A- ${ }^{131} \mathrm{I}$, the lymphocytes were washed with $5 \mathrm{ml} 0.9 \% \mathrm{NaCl}$. The cell pellets were then transferred to a second set of presoaked tubes with another $5 \mathrm{ml} 0.9 \% \mathrm{NaCl}$ and the cells sedimented and counted in a Packard Autogamma Counter. This precaution effectively reduced background radioactivity caused by nonspecific adherence to the counting tubes. In addition, parallel incubations were carried out in the presence and absence of $0.2 \mathrm{M} \alpha$-methyl glucose, a potent hapten inhibitor of specific Con-A binding (11). Residual binding in the presence of $\alpha$-methyl glucose $(10-25 \%$ of total radioactivity bound) was considered to be nonspecific, and appropriate corrections for this were made in the computation of binding curves.

Fluorescein-conjugated mitogens. Fluorescein-conjugated Con-A was prepared by a modification of the method reported by Tkacz, Cybulska, and Lampen (12). Con-A, 11.9 $\mathrm{mg}$, and $0.45 \mathrm{mg}$ fluorescein isothiocyanate (FITC) were incubated in $1 \mathrm{ml} 1 \mathrm{M} \mathrm{NaCl}$ at room temperature for $2 \mathrm{hr}$. The reaction mixture was then dialyzed overnight against 2 liters of $1 \mathrm{M} \mathrm{NaCl}$ at $4^{\circ} \mathrm{C}$. Residual unconjugated FITC was removed by filtration through an $0.8-\times-14 \mathrm{~cm}$ column packed with Biogel P-10 (Bio-Rad Laboratories, Richmond, Calif.) which was equilibrated with $0.9 \% \mathrm{NaCl}$. Fluoresceinconjugated E-PHA was prepared by a similar procedure. For studies of fluorescent mitogen binding to lymphocytes, $3.5 \times 10^{6}$ cells were incubated in $0.5 \mathrm{ml}$ serum-free medium199 with $40 \mu \mathrm{g} / \mathrm{ml}$ fluorescein-conjugated Con-A or $30 \mu \mathrm{g} /$ $\mathrm{ml}$ fluorescein-conjugated E-PHA. When added to the incubation mixtures, the concentration of $\alpha$-methyl glucose was $0.4 \mathrm{M}$. Incubation was carried out for $10 \mathrm{~min}$ in $12-\mathrm{ml}$ conical glass tubes at $37^{\circ} \mathrm{C}$ in a $5 \% \mathrm{CO}_{2}$ atmosphere. Cells were washed, collected by centrifugation, then resuspended in $0.5 \mathrm{ml}$ medium. Wet mounts were prepared and examined immediately under an American Optical series V20 Fluorestar microscope (American Optical Corp., Buffalo, N. Y.).

\section{RESULTS}

Fractionation of lymphocytes on nylon columns. The results of a representative experiment examining the mitogenic response of filtered and unfiltered lymphocytes to each of three plant mitogens, Con-A, E-PHA, and PWM are shown in Table I. In this experiment ConA-stimulated DNA synthesis in unfiltered cells was 7 -fold greater than that in the filtered subpopulation. Consistent results were obtained in each of 15 separate experiments using lymphocytes derived from 12 individuals. The results for all experiments show that Con-A induced 6.5-fold greater DNA synthesis in the unfiltered population than in the filtered population. ConA-stimulated blast transformation was four- to fivefold greater in the unfiltered than in the filtered population. Values for percentages of lymphoblasts present at $72 \mathrm{hr}$ in the unfiltered cell cultures ranged between 25 and $40 \%$, whereas in the filtered cells the range was from 4 to $9 \%$. Similar results were obtained when the unfiltered cells were passed through a nylon column which was 13.4 $\mathrm{cm}$ in length rather than the usual $6.7 \mathrm{~cm}$. When the nylon column was only $3.3 \mathrm{~cm}$ long, the yield of lymphocytes was higher but the response of the filtered cells to Con-A was only slightly impaired. Both lymphocyte sub- populations responded maximally to Con- $A$ on the 4th day of culture (Fig. 1) indicating that these results are not due to the two cell populations reaching their peak response at different times.

When the response of the two lymphocyte populations to other plant mitogens was examined, only small differences were observed. In the experiment in Table I the unfiltered to filtered response ratios for E-PHA and PWM were 1.47 and 1.14 , respectively. The mean ratio $( \pm \mathrm{SE})$ for E-PHA as determined from 13 separate experiments was $1.46 \pm 0.11$, and the comparable figure for PWM determined from 6 experiments was $1.83 \pm 0.17$. Using the Student's $t$ distribution (13), the Con-A unfiltered to filtered response ratio of $6.49 \pm 1.08$ differs significantly from these values as calculated for E-PHA $(P<0.001)$ and for PWM $(P<0.025)$.

A portion of the cells adherent to the nylon could be removed by vigorous agitation of the fibers. With this technique only an additional $10 \%$ of the lymphocytes applied to the column were removed. When these cells were cultured with Con-A, their mitogenic response was found to be intermediate between that of the filtered and unfiltered populations, (Table II). Additional adherent cells could not be removed from the column despite elution with large volumes of medium (up to 1 liter), use of EDTA in various concentrations, or chilling to $4^{\circ} \mathrm{C}$. Because of these difficulties encountered in removing adherent lymphocytes from the nylon fibers, it was not feasible to obtain these cells in sufficient quantity for our experiments. Furthermore, it is possible that these ad-

TABLE II

Fractionation of Lymphocytes by Nylon Columns*

\begin{tabular}{lrrc}
\hline & \multicolumn{3}{c}{ Thymidine-8H incorpoated } \\
\cline { 2 - 4 } Mitogen & Unfiltered & Filtered & Adherent \\
\hline Con-A & 103,000 & 19,000 & 51,000 \\
E-PHA & 151,000 & 141,000 & - \\
None & 1,500 & 600 & -
\end{tabular}

* Unfiltered cells were prepared from defibrinated peripheral venous blood by dextran sedimentation and isopycnic centrifugation upon a Ficoll-Hypaque mixture. $283 \times 10^{6}$ unfiltered cells consisting of $60 \%$ lymphocytes, $29 \%$ polymorphonuclear leukocytes, $3 \%$ basophils, $1 \%$ eosinophils, and $7 \%$ monocytes were obtained from $450 \mathrm{cc}$ of blood. $120 \times 10^{6}$ unfiltered cells were passed through a nylon fiber column to obtain $25 \times 10^{6}$ filtered cells which were $100 \%$ lymphocytes (a lymphocyte yield of approximately $35 \%$ ). By vigorous agitation of the fibers in a beaker of medium-199, $10 \times 10^{6}$ adherent cells were recovered from the fibers. These consisted of $92 \%$ lymphocytes. Cultures were set up at a concentration of $4 \times 10^{6}$ lymphocytes per $2 \mathrm{ml}$ culture, and the uptake of thymidine-- ${ }^{3} \mathrm{H}$ into DNA was determined as described. 


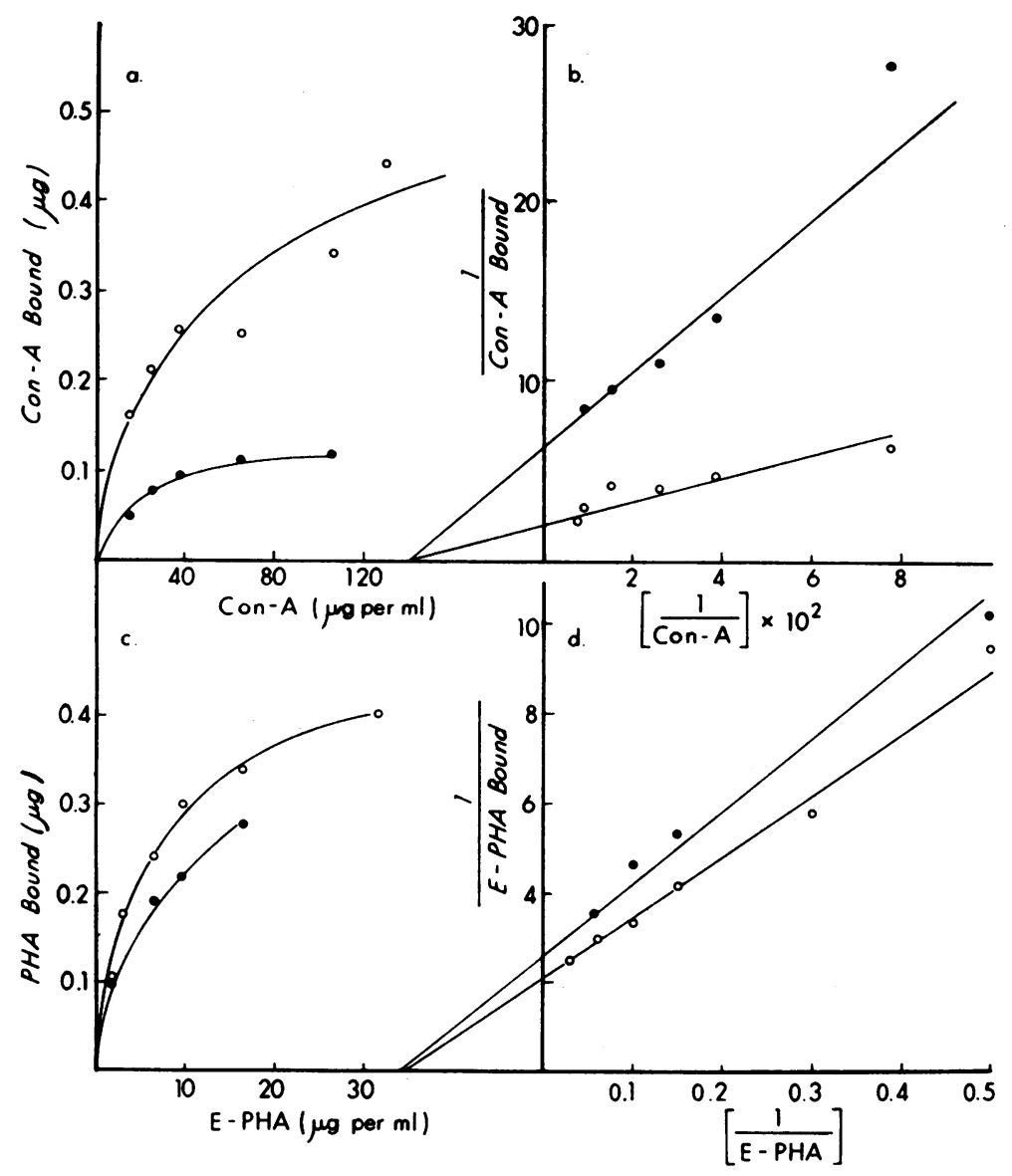

FIGURE 2 Binding of ${ }^{131}$ I-labeled mitogens to filtered and unfiltered lymphocytes. In plastic counting tubes $2 \times 10^{\circ}$ filtered or unfiltered cells ( $85 \%$ lymphocytes) were incubated at $25^{\circ} \mathrm{C}$ for $45 \mathrm{~min}$ in $0.4 \mathrm{ml}$ medium 199 containing $1 \mathrm{mg}$ bovine serum albumin and either 14 to $130 \mu \mathrm{g} / \mathrm{ml}$ Con-A-181 I or $2-32 \mu \mathrm{g} / \mathrm{ml} \mathrm{E-PHA-181} \mathrm{I}$. Con-A- ${ }^{131} \mathrm{I}$ incubations were performed in duplicate sets with and without $0.2 \mathrm{~m} \alpha$-methyl-D-glucose. Cells were harvested as described by washing twice with $5 \mathrm{ml} 0.9 \% \mathrm{NaCl}-0.01 \mathrm{M} \mathrm{NaHCO}$. After appropriate corrections for nonspecific binding to the plastic tubes, the data were plotted by the method of Steck and Wallach (14) according to the equation:

$$
\frac{1}{[M \text {-bound }]}=\frac{1}{K \cdot n \cdot C} \cdot \frac{1}{[M]}+\frac{1}{n \cdot C}
$$

where $M=$ concentration free mitogen $(\mu \mathrm{g} / \mathrm{ml}) ; n=$ number of mitogen binding sites per cells; and $C=$ number of cells. $K$ is the affinity constant of the mitogen. $\bullet$, filtered cells; $\bigcirc$, unfiltered cells.

herent cells are damaged by the manipulations necessary to remove them from the nylon.

Since the unfiltered cell population consists of $60-95 \%$ lymphocytes, we questioned whether the enhanced responsiveness to Con-A might reflect the activity of a "helper" cell. To test this possibility the following experiment was devised. Varying percentages of unfiltered cells were mixed with the filtered cells and incubations with Con-A were carried out as usual. If a helper cell were lacking in the filtered population, then the addition of the unfiltered fraction containing helper cells should restore full or nearly full activity. The data in Table III indicate that this did not occur, and we conclude therefore that the responsiveness of unfiltered lymphocytes to Con-A does not depend upon the presence of a helper cell.

In summary, when peripheral blood lymphocytes are passed through a nylon column, a subpopulation of lymphocytes highly responsive to - Con-A adheres to the fibers and is removed while a second subpopulation of cells relatively unresponsive to Con-A passes through and emerges from the column. 
Binding studies with Con- $A{ }^{131} I$. We next sought to determine if the difference in Con-A responsiveness of these two lymphocyte populations could reflect differences in the relative abilities of the cells to bind Con- $A$ to surface receptors. Binding studies were performed by incubating filtered and unfiltered lymphocytes for $45 \mathrm{~min}$ with varying concentrations of Con-A- ${ }^{131} \mathrm{I}$ in the presence and absence of $\alpha$-methyl glucose. After appropriate corrections had been made for nonspecific binding the data were plotted according to the method of Steck and Wallach (14) as shown in Fig. 2. From the double reciprocal plot (Fig. $2 b$ ) it was possible to determine the apparent association constant, $K$, for Con-A binding to the cells as well as the number of binding sites per cell (see Fig. 2 legend for details). Although both cell populations bind Con-A with essentially the same affinity (apparent association constant $K$ of $1.67 \times 10^{6} \mathrm{M}^{-1}$ ), the filtered cells bound significantly less Con-A than did the unfiltered cells. The maximum amount of the mitogen bound per $2 \times 10^{8}$ filtered cells was $0.16 \mu \mathrm{g}$ as compared to $0.5 \mu \mathrm{g}$ bound by the unfiltered cells. Assuming the mol wt of the Con-A molecule to be 55,000 (15) one can calculate the average maximum number of Con-A molecules bound per cell. This number is a measure of available receptor sites per cell. These values are $8.8 \times 10^{5}$ receptor sites per filtered lymphocyte compared to $2.7 \times$ $10^{8}$ for the unfiltered population. The mean number of receptor sites calculated for filtered cells in four experiments is $9.6 \times 10^{5}$ and the corresponding value for the unfiltered cells is $2.7 \times 10^{\circ}$. The actual differences between the number of receptor sites on nylon adherent and nonadherent cells are probably significantly greater since the unfiltered cell population contains both cell types.

The results of E-PHA- ${ }^{191} \mathrm{I}$ binding studies performed on the same preparation of filtered and unfiltered cells are shown in panels $c$ and $d$ of Fig. 2. The apparent $K$ for the filtered and unfiltered populations was determined to be $2 \times 10^{7} \mathrm{M}^{-1}$. Similarly the number of receptor sites for E-PHA was calculated to be $2.1 \times 10^{6}$ and $2.6 \times 10^{\circ}$ for filtered and unfiltered cells, respectively. The number of E-PHA molecules bound by normal human lymphocytes has previously been calculated to be $2.7 \times 10^{6}$ (10).

Studies with fluorescein-conjugated Con-A. The decreased Con-A binding by filtered cells could occur either because all the cells bound less Con-A or because some of the cells bound a normal amount of the mitogen while others bound none. To resolve this point, we did binding studies with fluorescein-conjugated Con-A and examined the cells to determine the relative distribution of Con-A binding among the lymphocyte populations. When lymphocytes were incubated with fluorescein-conjugated Con-A for periods of up to $1 \mathrm{hr}$, all cells were found
TABLE III

Effect of Mixing Filtered and Unfiltered Cells on Con-A Responsiveness*

\begin{tabular}{|c|c|c|c|c|c|}
\hline & & \multicolumn{4}{|c|}{ Percentage unfillered cells } \\
\hline & & 0 & 10 & 50 & 100 \\
\hline & & \multicolumn{4}{|c|}{$\begin{array}{l}\text { Thymidine-s } \mathrm{H} \text { incorporated, } \\
\qquad p m \times 10^{-3}\end{array}$} \\
\hline \multicolumn{6}{|l|}{ Donor A } \\
\hline $\begin{array}{l}\text { Con-A-stimulated } \\
\text { thymidine- }{ }^{3} \mathrm{H}\end{array}$ & Actual $\ddagger$ & 8.8 & 16.0 & 33.0 & 57.0 \\
\hline incorporation & Predicted $\S$ & - & 13.6 & 32.9 & - \\
\hline $\begin{array}{l}\text { E-PHA-stimulated } \\
\text { thymidine--3 } \mathrm{H}\end{array}$ & Actual & 53.0 & 64.0 & 66.0 & 82.0 \\
\hline incorporation & Predicted & - & 55.9 & 67.5 & - \\
\hline \multicolumn{6}{|l|}{ Donor B } \\
\hline $\begin{array}{l}\text { Con-A-stimulated } \\
\text { thymidine- }{ }^{3} \mathrm{H}\end{array}$ & Actual & 3.3 & 5.9 & 17.0 & 31.0 \\
\hline incorporation & Predicted & - & 6.1 & 17.2 & 一 \\
\hline \multirow{2}{*}{$\begin{array}{l}\text { E-PHA-stimulated } \\
\text { thymidine- }{ }^{-3} \mathrm{H} \\
\text { incorporation }\end{array}$} & Actual & 115.0 & 106.0 & 74.0 & 84.0 \\
\hline & Predicted & - & 111.9 & 99.5 & 一 \\
\hline
\end{tabular}

* Filtered and unfiltered lymphocyte populations were prepared as described and adjusted to contain equivalent lymphocyte concentrations. Replicate cultures were set up in 2-ml vol adding the indicated percentages of unfiltered cells to filtered cells. Incubation with $12.5 \mu \mathrm{g} / \mathrm{ml}$ Con-A or $15 \mu \mathrm{g} / \mathrm{ml}$ E-PHA proceeded for $72 \mathrm{hr}$ at which time incorporation of thymidine-- ${ }^{3} \mathrm{H}$ into DNA was determined.

$\ddagger$ Actual counts per minute $\times 10^{-3}$ as determined from the incorporation of thymidine- ${ }^{-3} \mathrm{H}$ into acid-insoluble radioactivity. $\$$ Counts per minute $\times 10^{-3}$ predicted assuming the contribution from each population to be solely additive.

to bind the mitogen. Since this technique is not a quantitative one, we could not determine whether some cells bound more Con-A than others. The predominant staining pattern was homogeneous fluorescence. However, approximately $10 \%$ of lymphocytes in the unfiltered cell population evidenced a striking polar localization of fluorescence which has been termed "cap formation" (16, 17). In contrast only $2 \%$ of the filtered cells manifested cap formation. The homogeneous fluorescence and cap formation were both abolished by incubation in the presence of $0.4 \mathrm{M} \alpha$-methyl glucose. When similar incubation studies were carried out with fluorescein-conjugated E-PHA, all cells again bound fluorescent material in a predominantly homogeneous pattern. Approximately 5\% of both subpopulations, filtered and unfiltered, manifested cap formation with E-PHA.

Effects of Con- $A$ concentration on DNA synthesis. To determine the relationship between Con-A binding and the stimulation of DNA synthesis, we studied the effect on DNA synthesis of incubating the two lympho- 


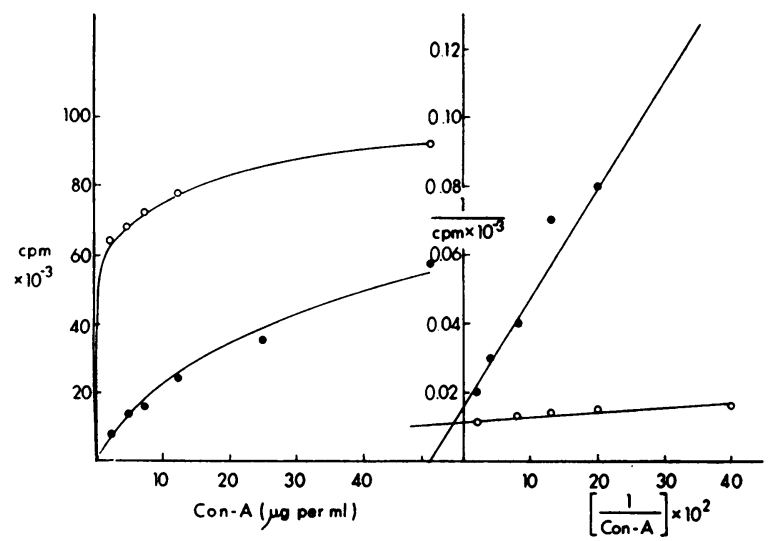

Figure 3 Relationship between mitogen concentration and DNA synthesis in filtered and unfiltered lymphocytes. $2 \times$ $10^{6}$ filtered and unfiltered cells were incubated for $72 \mathrm{hr}$ at $37^{\circ} \mathrm{C}$ with $2.5-50 \mu \mathrm{g} / \mathrm{ml}$ Con-A. After a $4 \mathrm{hr}$ pulse with $3 \mu \mathrm{Ci}$ thymidine $-{ }^{3} \mathrm{H}$, cells were harvested as described and the incorporation of radioactivity into acid-insoluble material was determined. The data were plotted according to Lineweaver and Burk (19) and the apparent Michaelis constant for mitogenesis determined. $\bullet$, filtered cells; $O$, unfiltered cells.

cyte subpopulations with increasing concentrations of Con-A. For these experiments decomplemented autologous serum was used since it has been shown that the toxicity associated with high concentrations of Con-A is mediated by complement (18). At concentrations greater than approximately $75 \mu \mathrm{g} / \mathrm{ml}$ however. Con-A forms precipitates with various serum components which appears to limit the maximum effective concentration. Representative concentration curves for filtered and unfiltered cells in decomplemented serum are shown in Fig. 3 . In this experiment the concentration of Con-A required to achieve half-maximal stimulation of DNA synthesis was 14-fold greater for the filtered cells compared to the unfiltered cells $(20 \mu \mathrm{g} / \mathrm{ml}$ vs. $1.4 \mu \mathrm{g} / \mathrm{ml})$. Although the filtered subpopulation responded poorly to Con-A at low mitogen concentrations, the maximal rate of DNA synthesis achieved at very high Con-A concentrations by this cell population approached that of the unfiltered cells. The absolute concentrations of Con-A required to achieve half-maximal DNA stimulation varied considerably from experiment to experiment, but in all instances the unfiltered cells responded to lower concentrations of Con-A than the filtered cells (Table IV). Also shown in Table IV is an estimate of the amount of Con-A bound to the lymphocytes when half-maximal stimulation of DNA synthesis is achieved. These data were obtained by interpolation of the values of Con-A concentration required for half-maximal DNA synthesis onto the ConA $-^{13}$ I binding curve (Fig. 2).

Stimulation with more than one mitogen. In an attempt to determine whether Con-A and E-PHA stimu- lated the same or different lymphocytes, we incubated unfiltered and filtered cells with both mitogens for $72 \mathrm{hr}$. As shown in Table $\mathrm{V}$, the two mitogens together produced no additive effect. In the experiment with the unfiltered cells, slight inhibition was observed when both mitogens were present compared to the use of either mitogen alone. A similar finding has been reported by Möller, who noted an antagonistic effect when two nonspecific mitogens were added in optimal concentrations to lymphocyte cultures (20). Therefore it seems likely that the lymphocytes which respond to Con-A also respond to E-PHA. However, there may be lymphocytes which respond to E-PHA but not to Con-A.

Studies of lymphocytes from chronic lymphocytic leukemia patients. Peripheral blood lymphocytes from nine patients with chronic lymphocytic leukemia (CLL) were tested for their adherence to nylon fibers and for responsiveness to E-PHA and Con-A. Results of studies of the adherence of normal and CLL lymphocytes to nylon fibers are given in Table VI. An average ( \pm SE) of 75.1 $2.8 \%$ of CLL lymphocytes adhered to the nylon columns compared to only $40.2 \pm 4.9 \%$ of normal lymphocytes. These percentages differ significantly $(P<0.001$, Student's $t$ test). Typical patterns of responsiveness of unfiltered and filtered CLL lymphocytes to Con-A and E-PHA are shown in Table VII. The average result from nine experiments was that Con-A induced $3.1 \pm 0.7$ fold greater DNA synthesis at day 5 in the unfiltered

TABLE IV

Relationship between Con-A Binding and Mitogenesis in Filtered and Unfiltered Lymphocytes*

\begin{tabular}{clcc}
\hline Experiment & Cells & $\begin{array}{c}\text { Concentration of } \\
\text { Con-A for half- } \\
\text { maximal DNA } \\
\text { synthesis }\end{array}$ & $\begin{array}{c}\text { Estimated Con-A } \\
\text { bound at half- } \\
\text { maximal DNA } \\
\text { synthesis }\end{array}$ \\
\hline \multirow{3}{*}{1} & & $\mu g / m l$ & $\mu g \ddagger$ \\
& Unfiltered & 1.4 & 0.050 \\
2 & Filtered & 20.0 & 0.065 \\
& Unfiltered & 8.5 & 0.130 \\
& Filtered & 33.0 & 0.085 \\
& Unfiltered & 7.5 & 0.120 \\
& Filtered & 39.0 & 0.090 \\
\hline
\end{tabular}

* Filtered and unfiltered cells were prepared and incubated for $72 \mathrm{hr}$ with varying concentrations of Con- $\mathrm{A}$ in the presence of decomplemented serum. The incorporation of thymidine- ${ }^{3} \mathrm{H}$ into acid-insoluble material was then determined as described. The data were plotted according to the method of Lineweaver and Burk (19) as demonstrated in Fig. 3 for the results in experiment 1 .

$\ddagger$ These data were calculated by interpolation of the values for Con-A concentration at half-maximal DNA synthesis onto the Con-A-131I binding curve (Fig. 2) to give micrograms Con-A bound per $2 \times 10^{6}$ cells. 
TABLE V

Attempt to Demonstrate Additive Effects of Con-A and E-PHA*

\begin{tabular}{|c|c|c|c|c|}
\hline \multirow[b]{2}{*}{ Mitogen } & \multicolumn{2}{|c|}{$\begin{array}{l}\text { Thymidine-3 } \mathrm{H} \\
\text { incorporated }\end{array}$} & \multicolumn{2}{|c|}{$\begin{array}{l}\text { Lymphoblast } \\
\text { formation }\end{array}$} \\
\hline & Unfiltered & Filtered & Unfiltered & Filtered \\
\hline & \multicolumn{2}{|c|}{$c p m$} & \multicolumn{2}{|l|}{$\%$} \\
\hline Con-A & 117,000 & 24,000 & 39 & 7 \\
\hline E-PHA & 79,000 & 54,000 & 96 & 91 \\
\hline Con-A and E-PHA & 68,000 & 51,000 & - & 一 \\
\hline
\end{tabular}

* The incorporation of thymidine-- ${ }^{3} \mathrm{H}$ into DNA was determined in cultures of filtered and unfiltered cells stimulated by Con-A alone, E-PHA alone, or both Con-A and E-PHA together. Concentrations used were Con- $\mathrm{A}, 12.5 \mu \mathrm{g} / \mathrm{ml}$ and E-PHA, $15 \mu \mathrm{g} / \mathrm{ml}$. Methods used were described previously $\ddagger$ Cells were evaluated in wet mounts with supravital staining. 500 cells were counted in each case.

cells than in the filtered cells while the comparable figure for E-PHA was $1.3 \pm 0.2$.

\section{DISCUSSION}

These data demonstrate that human peripheral blood contains two subpopulations of lymphocytes which differ in their responsiveness to the plant mitogen Con-A. These subpopulations are readily separated from one another since the more responsive cells adhere to nylon fibers while the poorly responsive cells do not. Although the cell surface properties which lead to nylon adherence are not known, the fact that these two lymphocyte subpopulations differed in this property suggested that their cell surfaces were different. And since the initial step in lymphocyte activation by the plant mitogens involves binding of the molecules to glycoprotein receptors on the cell surface $(4,5,11,21-26)$, it seemed reasonable that these two lymphocyte populations might differ in their ability to bind Con-A, thus explaining the difference in their responsiveness to this mitogen. This hypothesis proved to be the case as the Con-A- $-{ }^{131} \mathrm{I}$ binding studies (Fig. 2) revealed that the unfiltered lymphocytes contain approximately three times as many Con-A receptor sites as the filtered cells although both cell types bind the mitogen with the same affinity. In contrast, the unfiltered cells bound only slightly more E-PHA than did the filtered cells, indicating a selective difference in the surface properties of the two lymphocyte populations. The results of the binding studies correlate well with the finding that the difference in DNA responsiveness between the two populations is much greater with Con-A than with E-PHA.

An essential question raised by these studies is what is the relationship between Con-A binding to the cell surface receptors and the subsequent stimulation of DNA synthesis?
As shown in Fig. 3, the filtered lymphocytes are capable of responding adequately to Con- $\mathrm{A}$ when the cells are incubated with high concentrations of the mitogen in the presence of preheated serum in which the complement-dependent cytotoxicity of Con-A is avoided. In fact at very high Con-A concentrations the response of the filtered cells approaches that of the unfiltered cells. This observation indicates that the filtered cells possess the necessary cellular machinery to mount an adequate mitogenic response and points to the relative paucity of surface receptors as the critical feature in their failure to respond to lower concentrations of Con-A. ${ }^{2}$

These relationships can be better appreciated by examining the data in Table IV which give the concentration of Con-A necessary to induce half-maximal DNA synthesis in the two lymphocyte subpopulations. These values indicate that the unfiltered lymphocytes are several-

TABLE VI

Adherence of Lymphocytes from Normal Individuals and Patients with CLL to Nylon Fibers*

\begin{tabular}{|c|c|c|c|c|c|}
\hline & $\begin{array}{l}\text { White blood } \\
\text { cell count }\end{array}$ & $\begin{array}{l}\text { Lympho- } \\
\text { cytes }\end{array}$ & $\begin{array}{l}\text { Lymphocytes } \\
\text { applied } \\
\text { to column }\end{array}$ & $\begin{array}{l}\text { Lympho- } \\
\text { cytes } \\
\text { recovered }\end{array}$ & Adherence \\
\hline & cells $/ \mathrm{mm}^{2}$ & $\%$ & cells & $\times 10^{-6}$ & $\%$ \\
\hline \multicolumn{6}{|l|}{ Patients } \\
\hline F. F. & 14,800 & 71 & 32.4 & 8.3 & 75 \\
\hline M. S. & 15,700 & 77 & 34.2 & 8.5 & 75 \\
\hline A. $\mathrm{S}$. & 17,000 & 71 & 83 & 22 & 74 \\
\hline H. $\mathbf{R}$. & 22,000 & 85 & 105 & 34 & 68 \\
\hline J. Y. & 24,500 & 79 & 85 & 8 & 90 \\
\hline F. Pr. & 27,000 & 67 & 92 & 30 & 68 \\
\hline R. S. & 27,300 & 78 & 64 & 10 & 84 \\
\hline M. D. & 29,000 & 97 & 98 & 36 & 63 \\
\hline \multirow[t]{2}{*}{ F. Po. } & 50,000 & 95 & 107 & 23 & 79 \\
\hline & & & & Average $( \pm \mathrm{SE})$ & $75.1 \pm 2.8$ \\
\hline \multicolumn{6}{|c|}{ Normal subjects } \\
\hline C. S. & - & 一 & 72 & 65.5 & 10 \\
\hline S. $\mathbf{K}$. & - & - & 94 & 49 & 48 \\
\hline J. F. & - & 一 & 95 & 56.8 & 40 \\
\hline J. Ba. & - & - & 100 & 68 & 32 \\
\hline M. E. & - & 一 & 100 & 64 & 36 \\
\hline K. D. & - & - & 100 & 44 & 56 \\
\hline J. Be. & 一 & - & 100 & 73 & 27 \\
\hline P. S. & - & - & 72 & 25 & 65 \\
\hline N. B. & - & - & 100 & 55 & 45 \\
\hline \multirow[t]{2}{*}{ W. E. } & 一 & - & 100 & 57 & 43 \\
\hline & & & & Average $( \pm S E)$ & $40.7 \pm 4.9$ \\
\hline
\end{tabular}

* Peripheral venous blood from patients with CLL and from healthy volunteers was processed as described in the methods. Per cent adherent lymphocytes was determined from cell counts and differentials performed before and after filtration through a $2.8 \times 6.7 \mathrm{~cm}$ column packed with nylon fibers. Eight of the nine subjects with CCL were receiving no specific therapy for CLL at the time of this study. One subject (M. D.) was receiving $100 \mathrm{mg}$ prednisone twice weekly.

${ }^{2}$ This finding also indicates that the filtered lymphocytes have not been damaged by passage through the nylon column. The fact that the filtered cells respond to E-PHA and PWM almost as well as unfiltered cells provides further evidence that the filtered cells are not damaged in their preparation. 
TABLE VII

Response of Lymphocytes from Patients with CLL to Plant Mitogens*

\begin{tabular}{|c|c|c|c|c|c|c|c|}
\hline \multirow[b]{2}{*}{ Patient } & \multirow[b]{2}{*}{ Mitogen } & \multicolumn{3}{|c|}{ Day 3} & \multicolumn{3}{|c|}{ Day 5} \\
\hline & & Unfiltered & Filtered & Ratio & Unfiltered & Filtered & Ratio \\
\hline & & \multicolumn{3}{|c|}{$c p m$} & \multicolumn{3}{|c|}{$c p m$} \\
\hline \multirow[t]{3}{*}{ F. Pr. } & None & 2,100 & 2,500 & 0.8 & 4,500 & 6,400 & 0.7 \\
\hline & E-PHA & 45,300 & 28,100 & 1.6 & 45,900 & 36,100 & 1.3 \\
\hline & Con-A & 62,900 & 21,200 & 3.0 & 91,000 & 31,400 & 2.9 \\
\hline \multirow[t]{3}{*}{ H. R. } & None & 1,210 & 1,200 & 1.0 & 890 & 650 & 1.4 \\
\hline & E-PHA & 73,310 & 41,940 & 1.7 & 40,360 & 29,440 & 1.4 \\
\hline & Con-A & 161,620 & 59,740 & 2.7 & 203,760 & 37,890 & 5.4 \\
\hline \multirow[t]{3}{*}{ A.S. } & None & 770 & 1,250 & 0.6 & 730 & 2,110 & 0.3 \\
\hline & E-PHA & 80,400 & 52,560 & 1.5 & 92,460 & 78,110 & 1.2 \\
\hline & Con-A & 124,570 & 66,740 & 1.9 & 168,820 & 69,290 & 2.4 \\
\hline \multirow[t]{3}{*}{ F. Po. } & None & 200 & 400 & 0.5 & 500 & 400 & 1.3 \\
\hline & E-PHA & 11,800 & 23,100 & 0.5 & 33,400 & 39,900 & 0.8 \\
\hline & Con-A & 22,900 & 45,800 & 0.5 & 118,300 & 161,200 & 0.7 \\
\hline
\end{tabular}

* Unfiltered and filtered lymphocytes were prepared from patients with CLL as described in the methods. Peripheral white blood cell counts of the patients represented were: F. Pr. 27,000, H. R. 22,000, A. S. 17,000 , and F. Po. 50,000. Triplicate 2 -ml clutures containing $2-3 \times 10^{6}$ lymphocytes were incubated for 72 or $120 \mathrm{hr}$ with $12.5 \mu \mathrm{g} / \mathrm{ml}$ Con-A or $15 \mu \mathrm{g} / \mathrm{ml} \mathrm{E}$-PHA. The uptake of thymidine- ${ }^{3} \mathrm{H}$ into DNA was determined as described.

fold more sensitive to the mitogenic effect of Con-A than the filtered lymphocytes. When these values are interpolated onto the Con-A- ${ }^{131} \mathrm{I}$ binding curve (Fig. 2), an important relationship emerges. That is both cell populations bind approximately the same amount of Con-A when they are exposed to the mitogen at the concentration which induces half-maximal DNA synthesis (Table IV).

These data suggest that a critical number of receptor sites must be occupied in order to elicit cell activation. However, it takes a higher concentration of Con-A to saturate the requisite number of receptor sites on the filtered cells. The reason for this difference is best appreciated by examining the binding reaction as a function of Con-A concentration. It is assumed that the binding of Con-A to the cell surface receptors is a reversible reaction following the law of mass action. The reaction can be written

$$
\text { Con-A }+R \underset{k_{2}}{\stackrel{k_{1}}{\rightleftharpoons}} \text { Con-A } \cdot R,
$$

where $R=n C$ and $n=$ number of receptors per cell while $C=$ concentration of cells. Since the filtered cells have a lower density of receptors (i.e., a lower $n$ ) than the unfiltered cells, a higher concentration of Con-A will be necessary to achieve the same number of complexed receptor sites (Con-A.R) when equal numbers of both cell populations are tested.
We cannot determine from the binding curves whether Con-A, a bivalent molecule (27), binds monovalently or bivalently to the cell surface receptors. The estimates of the number of Con-A and E-PHA cell surface receptors are based on the assumption that the phytomitogens bind monovalently to the lymphocyte cell surface. If the mitogen binding is, in fact, bivalent, then the number of receptors will have been underestimated by as much as twofold.

The possibility that the filtered and unfiltered lymphocytes are characterized by structurally different Con-A receptor sites cannot be excluded. However, the fact that the binding studies indicate that both lymphocyte populations have an essentially identical apparent association constant $(K)$ for Con-A binding makes this possibility less likely.

Since numerous sophisticated techniques have been applied to the fractionation of lymphocytes in lower animals, functionally distinct subpopulations are well recognized. In the mouse, thymus-dependent $(T)$ and thymusindependent (B) cell populations are recognized (reviewed in reference 28 ), the former characterized by the presence of a unique surface marker, the theta antigen $(29,30)$, and the latter by detectable surface-bound immunoglobulins $(16,31)$, and receptors for antigen-antibody-complement complexes $(32,33)$.

Although the same functional heterogeneity of lymphocytes is presumed to obtain in man, fractionation of human lymphoid cells into identifiable subpopulations has 
proved difficult. The various immune deficiency disorders have served as experiments of nature suggesting that human lymphocytes are functionally heterogeneous (34). Recently several investigators have reported on the presence of human lymphocytes bearing detectable surface immunoglobulins (35-37) and evidence for a subpopulation with complement receptors has appeared (38). But despite accumulating evidence that human lymphocytes are indeed a heterogeneous population of cells, it has been difficult to obtain isolated functional subpopulations. The technique of filtering lymphocytes through a column of nylon fibers offers a simple means for fractionating human lymphocytes into functionally distinct subpopulations. Thus Eisen, Wedner, and Parker, ${ }^{3}$ using this technique, have found that human lymphocytes with detectable surface-bound immunoglobulins are selectively adsorbed to the nylon fibers. These investigators are currently testing the response of these lymphocyte subpopulations to a variety of antigens (C. W. Parker, personal communication). It is of interest that the average percentage of nylon adherent lymphocytes that we have found in normal individuals (41\%) correlates reasonably well with reported values for the percentage of normal circulating lymphocytes bearing easily detectable surface immunoglobulins (36, 39,40 ).

Recent work suggests that CLL is a monoclonal proliferative disorder of B lymphocytes $(36,39,40)$. Thus CLL lymphocytes possess readily detectable surface immunoglobulins that are of a uniform subgroup on the cells of a given individual. The percentage of circulating lymphocytes bearing immunoglobulin determinants is markedly increased in patients with this disorder $(36,39$, 40 ). We have found that $75 \%$ of lymphocytes from nine patients with CLL adhere to nylon fibers as opposed to $41 \%$ of normal lymphocytes. A similar finding was reported by Thomson, Robinson, and Wetherley-Mein (41) who found a mean of $76 \%$ of CLL peripheral blood lymphocytes from six patients adherent to a column of polystyrene beads compared to only $27 \%$ adherent peripheral blood lymphocytes from 13 normal subjects. Our results are thus consistent with the current interpretation of CLL as a monoclonal B cell disorder.

When the CLL lymphocytes were passed over the nylon columns, the Con-A-stimulated DNA synthesis was only 3.1-fold greater in the unfiltered cells than in the filtered cells compared to a 6.5-fold difference when lymphocytes from normal individuals were tested. Yet if all the peripheral blood lymphocytes in the patients with CLL were truly monoclonal, one might expect that the response to Con-A would be unaffected by nylon

${ }^{3}$ Eisen, S. A., H. J. Wedner, and C. W. Parker. 1973. Isolation of pure human peripheral blood T-lymphocytes using nylon wool columns. Immunol. Commun. In press. column filtration. One possible explanation is that a certain percentage of the peripheral blood lymphocytes in our CLL patients were normal lymphocytes and that these normal cells accounted for the differential Con-A effect on DNA synthesis. Another possibility is that the great majority of the CLL lymphocytes are really monoclonal but that heterogeneity exists in the surface properties of the cells, resulting in variable adherence to nylon fibers and in responsiveness to Con-A. Either of these possibilities could explain why only $75 \%$ of the lymphocytes adhered to the nylon columns when $100 \%$ adherence would be expected of a true monoclonal population. Further experiments will be required to resolve this point.

\section{ACKNOWLEDGMENTS}

This research was supported in part by Grants HE-00022, R01 CA-80759, and HE-14147 from the U. S. Public Health Service.

\section{REFERENCES}

1. Hungerford, D. A., A. J. Donelly, P. C. Nowell, and S. Beck. 1959. The chromosome constitution of a human phenotypic intersex. Am. J. Hum. Genet. 11: 215.

2. Nowell, P. C. 1960. Phytohemagglutinin: an initiator of mitosis in cultures of normal human leukocytes. Cancer Res. 20: 462.

3. Naspitz, C. K., and M. Richter. 1968. The action of phytohemagglutinin in vivo and in vitro, a review. Prog. Allergy. 12: 1.

4. Mitchison, N. A. 1971. Control of the immune response by events at the lymphocyte surface. In Vitro. 7: 88.

5. Greaves, M. F., and S. Bauminger. 1972. Activation of $\mathrm{T}$ and $\mathrm{B}$ lymphocytes by insoluble phytomitogens. Nat. New Biol. 235: 67.

6. Weber, T., C. T. Nordman, and R. Gräsbeck. 1967. Separation of lymphocyte-stimulating and agglutinating activities in phytohaemagglutinin (PHA) from Phaeseolus vulgaris. Scand. J. Haematol. Suppl. 4: 77.

7. Mendelsohn, J., S. A. Skinner, and S. Kornfeld. 1971. The rapid induction by phytohemagglutinin of increased $\alpha$-amino-isobutyric acid uptake by lymphocytes. J. Clin. Invest. 50: 818 .

8. Bray, G. A. 1960. A simple efficient liquid scintillator for counting aqueous solutions in a liquid scintillation counter. Anal. Biochem. 1: 279.

9. Hunter, W. M. 1967. The preparation of radioiodinated proteins of high activity, their reaction with antibody in vitro: the radioimmunoassay. In Handbook of Experimental Immunology. D. M. Weir, editor. Blackwell Scientific Publications Ltd., Oxford, England. 608.

10. Kornfeld, S. 1969. Decreased phytohemagglutinin receptor sites in chronic lymphocytic leukemia. Biochim. Biophys. Acta. 192 : 542.

11. Goldstein, I. J., C. E. Hollerman, and E. E. Smith. 1965. Protein carbohydrate interaction. II. Inhibition studies on the interaction of concanavalin-A with polysaccharides. Biochemistry. 4: 876.

12. Tkacz, J. S., E. B. Cybulska, and J. O. Lampen. 1971. Specific staining of wall mannan in yeast cells with fluorescein-conjugated concanavalin A. J. Bacteriol. 105: 1. 
13. Snedecor, G. W. 1956. Applied to experiments in agriculture and biology. In Statistical Methods. Iowa State University Press, Ames. 5th edition. 45.

14. Steck, T. L., and D. F. H. Wallach. 1965. The binding of kidney-bean phytohemagglutinin by Ehrlich ascites carcinoma. Biochim. Biophys. Acta. 97: 510.

15. Kalb, A. J., and A. Lustig. 1968. The molecular weight of concanavalin A. Biochim. Biophys. Acta. 168: 366.

16. Raff, M. C., M. Sternberg, and R. B. Taylor. 1970. Immunoglobulin determinants on the surface of mouse lymphoid cells. Nature (Lond.). 225 : 553.

17. Raff, M. C. 1970. Two distinct populations of peripheral lymphocytes in mice distinguishable by immunofluorescence. Immunology. 19 : 637.

18. Milthorp, P., and D. R. Forsdyke. 1970. Activation by concanavalin $\mathrm{A}$ and phytohemagglutinin of rat lymphocytes in homologous or heterologous serum: dependence of inhibition at high concanavalin $\mathrm{A} /$ serum ratios on complement. In Proceedings of the Fifth Leukocyte Culture Conference. J. E. Harris, editor. Academic Press, Inc., New York. 143.

19. Lineweaver, H., and D. Burk. 1934. The determination of enzyme dissociation constants. J. Am. Chem. Soc. $56: 658$.

20. Möller, G. 1970. Induction of DNA synthesis in human lymphocytes: interaction between nonspecific mitogens and antigens. Immunology. $19: 583$.

21. Hirschhorn, K., R. L. Kolodney, N. Hashem, and F. Bach. 1963. Mitogenic action of phytohaemagglutinin. Lancet. $11: 305$.

22. Vassar, P. S., and C. F. A. Culling. 1964. Cell surface effects of phytohaemagglutinin. Nature (Lond.). 202: 610.

23. Allan, D., J. Auger, and M. J. Crumpton. 1971. Interaction of phytohemagglutinin with plasma membranes of pig lymphocytes and thymus cells. Exp. Cell Res. 66: 362.

24. Powell, A. E., and M. A. Leon. 1970. Reversible interaction of human lymphocytes with the mitogen concanavalin A. Exp. Cell Res. 62: 315.

25. Kornfeld, R., and S. Kornfeld. 1970. The structure of a phytohemagglutinin receptor site from human erythrocytes. J. Biol. Chem. 245: 2536.

26. Kornfeld, S., J. Rogers, and W. Gregory. 1971. The nature of the cell surface receptor site for Lens culinaris phytohemagglutinin. J. Biol. Chem. 246: 6581.

27. So, L. L., and I. J. Goldstein. 1968. Protein-carbohydrate interaction. XX. On the number of combining sites on concanavalin A, the phytohemagglutinin of the jack bean. Biochim. Biophys. Acta. 165: 398.
28. Davies, A. J. S., E. Leuchars, V. Wallis, and M. J. Doenhoff. 1971. A system for lymphocytes in the mouse. Proc. R. Soc. Lond. B. Biol. Sci. 176: 369.

29. Reif, A. E., and J. M. V. Allen. 1964. The AKR thymic antigen and its distribution in leukemias and nervous tissues. J. Exp. Med. 120: 413.

30. Schlesinger, M., and I. Yron. 1970. Serologic demonstration of a thymus-dependent population of lymphnode cells. J. Immunol. $104: 798$.

31. Unanue, E. R., H. M. Grey, E. Rabellino, P. Campbell, and J. Schmidtke. 1971. Immunoglobulins on the surface of lymphocytes. II. The bone marrow as the main source of lymphocytes with detectable surface-bound immunoglobulin. J. Exp. Med. 133: 1188.

32. Bianco, C., R. Patrick, and V. Nussenzweig. 1970. A population of lymphocytes bearing a membrane receptor for antigen-antibody-complement complexes. I. Separation and characterization. J. Exp. Med. 132: 702.

33. Bianco, C., and V. Nussenzweig. 1971. Theta-bearing and complement-receptor lymphocytes are distinct populations of cells. Science (Wash. D. C.). 173: 154.

34. Gotoff, S. P. 1968. Lymphocytes in congenital immunological deficiency diseases. Clin. Exp. Immunol. 3: 843.

35. Smith, R. S., R. L. Longmire, R. T. Reid, and R. S. Farr. 1970. The measurement of immunoglobulin associated with human peripheral lymphocytes. J. Immunol. $104: 367$.

36. Grey, H. M., E. Rabellino, and B. Pirofsky. 1971. Immunoglobulins on the surface of lymphocytes. IV. Distribution in hypogammaglobulinemia, cellular immune deficiency, and chronic lymphatic leukemia. J. Clin. Invest. $50: 2368$.

37. Fröland, S., J. B. Natvig, and P. Berdal. 1971. Surfacebound immunoglobulin as a marker of B lymphocytes in man. Nat. New Biol. 234: 251.

38. Huber, H., G. Michlmayr, C. Huber, H. Asamer, and S. D. Douglas. 1971. In 13th International Congress of Hematology, Munich 1970. D. C. Dumonde, editor. Springer-Verlag, New York Inc., New York. 78.

39. Wilson, J. D., and G. J. V. Nossal. 1971. Identification of human $\mathrm{T}$ and $\mathrm{B}$ lymphocytes in normal peripheral blood and in chronic lymphocytic leukaemia. Lancet. 2: 788.

40. Papamichail, M., E. J. Holborow, H. I. Keith, and H. L. F. Currey. 1972. Subpopulations of human peripheral blood lymphocytes distinguished by combined rosette formation and membrane immunofluorescence. Lancet. $2: 64$.

41. Thomson, A. E. R., M. A. Robinson, and G. WetherleyMein. 1966. Heterogeneity of lymphocytes in chronic lymphocytic leukaemia. Lancet. 2: 200. 